\title{
Adaptive Strategies of Seedlings of Four Mediterranean Co-Occurring Tree Species in Response to Light and Moderate Drought: A Nursery Approach
}

\author{
Marta Pardos *(D) and Rafael Calama
}

Citation: Pardos, M.; Calama, R. Adaptive Strategies of Seedlings of Four Mediterranean Co-Occurring Tree Species in Response to Light and Moderate Drought: A Nursery Approach. Forests 2022, 13, 154 https: / / doi.org/10.3390/ f13020154

Academic Editor: Francois Girard

Received: 23 December 2021

Accepted: 18 January 2022

Published: 20 January 2022

Publisher's Note: MDPI stays neutral with regard to jurisdictional claims in published maps and institutional affiliations.

Copyright: (C) 2022 by the authors. Licensee MDPI, Basel, Switzerland. This article is an open access article distributed under the terms and conditions of the Creative Commons Attribution (CC BY) license (https:// creativecommons.org/licenses/by/ $4.0 /)$.
Forest Dynamics and Management Department, CIFOR (INIA, CSIC), crta Coruña Km 7.5, 28040 Madrid, Spain; rcalama@inia.es

* Correspondence: pardos@inia.es

\begin{abstract}
In Mediterranean environments, light and water are clearly dominant ecological drivers of seedling growth and survival, and their interaction could modify productivity and forest composition. We examine the early response of seedlings of four co-occurring Mediterranean tree species (Pinus pinea, Juniperus thurifera, Quercus ilex and Quercus faginea) grown in the nursery to differing light and water availability conditions. Morphological (survival, height, biomass) and physiological (shoot midday water potential, net photosynthesis, transpiration rate, stomatal conductance, Fv/Fm, PSII and ETR) traits were studied, along with biomass allocation traits and drought resistance and plasticity indices. A significant effect of both factors was mainly shown for growth and morphological traits, while survival, physiological traits and allometry were affected by either water availability or light, being more remarkable the effect of water availability over light. Drought severely limited $Q$. faginea's survival under both light intensities. The high plasticity of $J$. thurifera and $Q$. ilex seedlings to different light and water availability environments will confer these two species with an adaptive advantage in the early growth stages in comparison with $P$. pinea and $Q$. faginea seedlings. Thus, to maintain the codominance of the four species, silvicultural interventions should focus on the joint management of all of them.
\end{abstract}

Keywords: pine-oak-juniper mixed forests; partitioning; growth; physiological traits; adaptive plasticity; regeneration niche

\section{Introduction}

Light and water availability at stand level are environmental factors that greatly conditioned survival, growth and regeneration dynamics of forest species [1-3]. Their interactive effect occurs in a great variety of site conditions [4], and could modify productivity and forest composition [5]. The complex interactions and trade-offs between light and water availability have helped to determine the optimal regeneration niche of a wide range of forest species [6-9]. Understanding how such interactions affect seedling performance will be especially relevant in those regions that show a marked drought season and that are highly sensible to the effects of climate change [10]. This is the case of the Mediterranean continental environments, which show higher vulnerability to climate change than other regions in Europe [11].

Mediterranean continental forests are highly constrained by dry conditions and high solar loads, mainly in the summer (e.g., [12]). These forests are characterized by the presence of only two to four species commonly distributed in contiguous patches dominated by one or other of the species. Thus, the loss of a species in these forests may have serious consequences as regards the functional ecology, since the species lost cannot be replaced by another species with a similar function [13]. This is aggravated by the fact that seedling survival and establishment in these forests are major bottlenecks to species recruitment. Thus, seedling abundance by itself may not guarantee the regeneration 
of the species (e.g., [14]). In addition, the projection of more frequent, longer, severe summer droughts and heat waves in the Mediterranean region (e.g., $[12,15])$ will hinder the successful establishment of tree seedlings in the short term and the regeneration of the stand in the long term.

Seedlings of coexisting tree species tend to have highly divergent morphological and physiological traits as well as noticeable functional variability within each species in response to light and water availability [13]. In these environments, seedlings of evergreen species are usually less vulnerable to drought-induced cavitation, whereas seedlings of winter deciduous species display drought avoidance during dry periods. Such differences are closely linked to leaf and stem structural characteristics [16,17].

Functional traits are increasingly the focus of research aimed at understanding the impact of climate change on forest ecosystems. Plants have the ability to cope with changes in the environmental conditions by varying different traits [18-20]. The probability of plants to survive under different climate change scenarios increases with higher intraspecific variability in some key traits [21]. This variability can be obtained through phenotypic plasticity, which refers to the range of different phenotypes that a single genotype can express depending on the environmental conditions. Phenotypic plasticity is essential for plant acclimation under climate change [22]. Understanding the functional traits that contribute to drought and light resistance of seedlings is important for predicting the distribution of the species under future fluctuations in water availability [23]. The analysis of these traits, and how they vary between species will be of particular relevance for future species coexistence and community dynamics. Thus, assessing seedling performance in coexisting species with different functional traits under various environmental conditions can help to explain their role in determining community composition [24]. In the Mediterranean region, the challenge over the coming years will be to determine how survival and growth respond to climate change and how to adapt forest management to buffer its negative impacts [17].

The correct interpretation of the interactive effect between light and water availability related to plant performance and distribution in their natural environments will require detailed studies carried out under natural conditions. However, under natural conditions, the isolation of the effects of each individual factor is difficult. Conversely, experiments carried out under controlled conditions can detect both the interactions and their separate effects, making it possible to interpret their implications for survival and growth of the studied species [4]. In this study, we focused in four co-occurring tree species found in Mediterranean continental forests in central Spain. These four species differ both in their strategies to cope with drought and in their light preferences, thus occupying distinct hydrological niches within the mixed forests [9]: a winter deciduous oak species (Quercus faginea Lam.) (hereafter $Q$. faginea), an evergreen sclerophyllous species (Quercus ilex L.) (hereafter $Q$. ilex), an early-successional drought-adapted conifer (Pinus pinea L.) (hereafter P. pinea), and a dioecious juniper species (Juniperus thurifera L.) (hereafter J. thurifera). Pinus pinea, described as isohydric, is a drought avoiding species, following a water saving and photoinhibition-tolerant strategy [12]. Quercus ilex, described as an anysohydric species, is a late-successional, slow-growing, water-spending, photoinhibition-avoiding species with a plastic hydraulic and morphological behaviour [15], able to grow during summer [25] Juniperus thurifera is an evergreen, long-living, slow-growing, water-saver conifer that will take advantage over the other coexisting species under severe drought conditions [9], able to maintain photosynthetic activity all the year, but with constrains in secondary growth during drought periods [26], and with a shallow root system [27]. Quercus faginea prefers mesic sites, shows an earlier phenological development in spring and higher conductance than Quercus ilex, but experiences xylem embolism due to summer drought [25]. Juniperus thurifera ise relatively more anisohydric than Pinus pinea, while Quercus faginea is especially vulnerable to drought. The management of these stands has historically focused on nut production in over-mature productive $P$. pinea trees, with firewood extraction from $Q$. ilex and $Q$. faginea or forage as secondary uses. Based on previous evidence, we hypothesized 
that the studied species display contrasting strategies to cope with drought, as well as different light preferences. To test this hypothesis, we performed a greenhouse experiment and used a trait-based approach to characterize seedlings responses to the combined effect of different water and light conditions in terms of survival, growth, biomass allocation and physiology. We first determined seedling survival and growth of the four species when exposed to the combined effect of two soil water conditions ( $\mathrm{W}+$ : field capacity; $\mathrm{W}-$ : medium soil moisture) and two light regimes (high and medium) for 12 months. Then, we further reduced the soil moisture in $\mathrm{W}$-during two more months in order to mimic the effect of summer drought, and different physiological and biomass allocation traits were assessed.

The quantification of trait variation across different watering and light levels allowed us to determine phenotypic responses of seedlings. Specifically, our aims were to (1) quantify the variability in the functional response among the coexisting species in Mediterranean continental forests in central Spain; and (2) to study the morphological mechanisms that underlay the response of the species in environments with differing light and water availability, when seedlings are grown under identical, controlled environmental conditions. The knowledge of the combined effects of light and soil moisture on seedling survival and performance is important to define guidelines for planning regeneration of these species in the mixed forest stands where they coexist. The particular characteristics of the environmental gradient in which these species live should also be considered. Thus, this knowledge will be of great importance for assessing possible changes in the distribution of these species under climate change scenarios.

\section{Materials and Methods}

\subsection{Plant Material and Methods}

The study was conducted with seedlings of four Mediterranean tree species ( $P$. pinea, J. thurifera, $Q$. ilex and $Q$. faginea) that coexist in the mixed forests within the limestone plain areas of the Spanish Northern Plateau. Seedlings were grown from seeds in the Central Nursery belonging to the Castilla-León regional government under standard growing conditions (FP containers $250 \mathrm{cc}$; soil was a mixture of peat, vermiculite and clay; seedlings were fertirrigated; oaks were grown in a greenhouse with no heating, while conifers were kept in the nursery under a shade cloth). Seeds were collected from 20-25 trees per species in a mixed natural forest in the Spanish Northern Plateau $\left(5^{\circ} 15^{\prime} \mathrm{W}\right.$, $41^{\circ} 28^{\prime} \mathrm{N}$ ). After one year, seedlings were transferred in June to a greenhouse where they were grown for the duration of the experiment (467 days). In this case, 192 seedlings (48 seedlings per species) were transplanted to 3-L pots filled with a mixture of peat and vermiculite $(3: 1, v: v)$. Seedlings were kept at field capacity for one month inside the greenhouse $\left(26.0^{\circ} \mathrm{C} \pm 2.4^{\circ} \mathrm{C}\right.$ day $/ 20.7{ }^{\circ} \mathrm{C} \pm 1.4^{\circ} \mathrm{C}$ night, $52 \pm 10$ per cent humidity, natural photoperiod) prior to initiating the experiment. Heights at the moment of initiating the experiment were $24.4 \pm 1.8 \mathrm{~cm}$ in $Q$. ilex, $36.2 \pm 0.8 \mathrm{~cm}$ in $P$. pinea, $19.7 \pm 1.0 \mathrm{~cm}$ in $J$. thurifera and $27.5 \pm 2.6 \mathrm{~cm}$ in $Q$. faginea.

After the 1-month acclimation period, seedlings were arranged in a split-plot experiment with two factors (light and water), each with two levels, and the treatments were replicated in 12 blocks. Seedlings were randomly divided into two groups, according to two light environments: (L+) 100\% sunlight inside the greenhouse and (L-) 40\% sunlight. Seedlings were grown under 12 open metal frames $(50 \times 80 \times 150 \mathrm{~cm}, 6$ blocks per light environment). Six of these metal frames had no shade (treatment L+) while the other six metal frames were covered with a neutral shade white cloth to create the $\mathrm{L}-$ environment. The average photosynthetic flux density under each light environment during a sunny day was $25.0 \mathrm{~mol} \mathrm{~m}^{-2}$ day $^{-1}$ in $\mathrm{L}+$ and $7.8 \mathrm{~mol} \mathrm{~m}^{-2}$ day $^{-1}$ in $\mathrm{L}-$. Light and temperature conditions throughout the experiment are shown in Figure 1. 

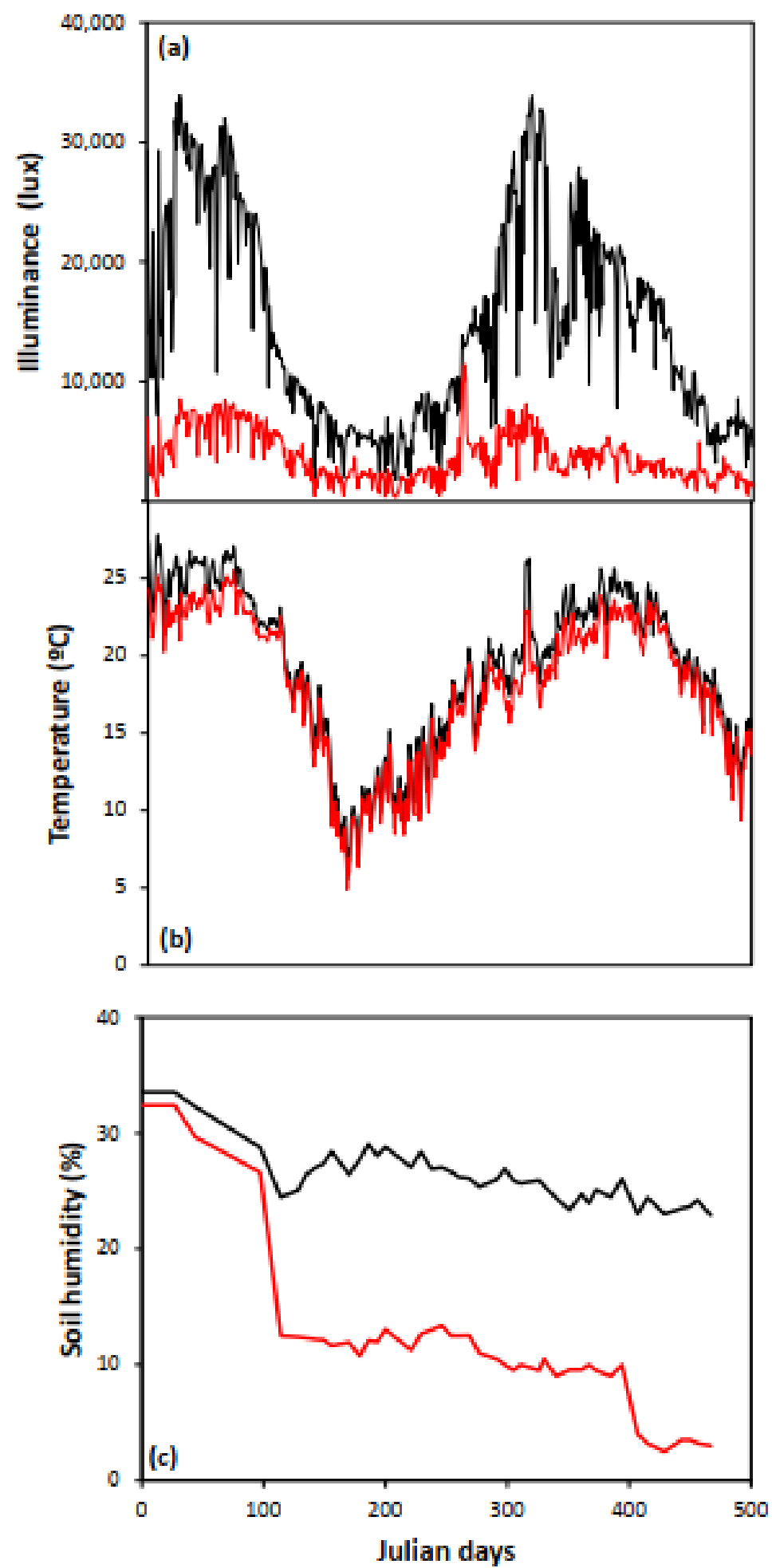

Figure 1. Environmental conditions in the greenhouse during the 467 days experimental period (starting in June). Light (a) and temperature (b) are shown for L+ (black line) and L- (red line) environments; while soil humidity (c) is shown for W+ (black line) and $\mathrm{W}-$ (red line) environments. The period when light and temperature decrease correspond to wintertime.

\subsection{Long-Term Drought Experiment}

A long-term drought experiment was set up from day 0 to day 394 to assess the effect of moderate drought on plant survival and growth. For this purpose, seedlings growing under each light treatment were divided into two groups and assigned to a water 
treatment (16 seedlings per block: 2 plants per species and water regime under each light environment) (Figure 2): (W+): well-watered seedlings, soil humidity was maintained up to $25.6 \pm 0.6 \%$, and $(\mathrm{W}-$ ): water-stressed seedlings, subjected to a moderate soil-water moisture condition of $10.5 \pm 1.1 \%$.

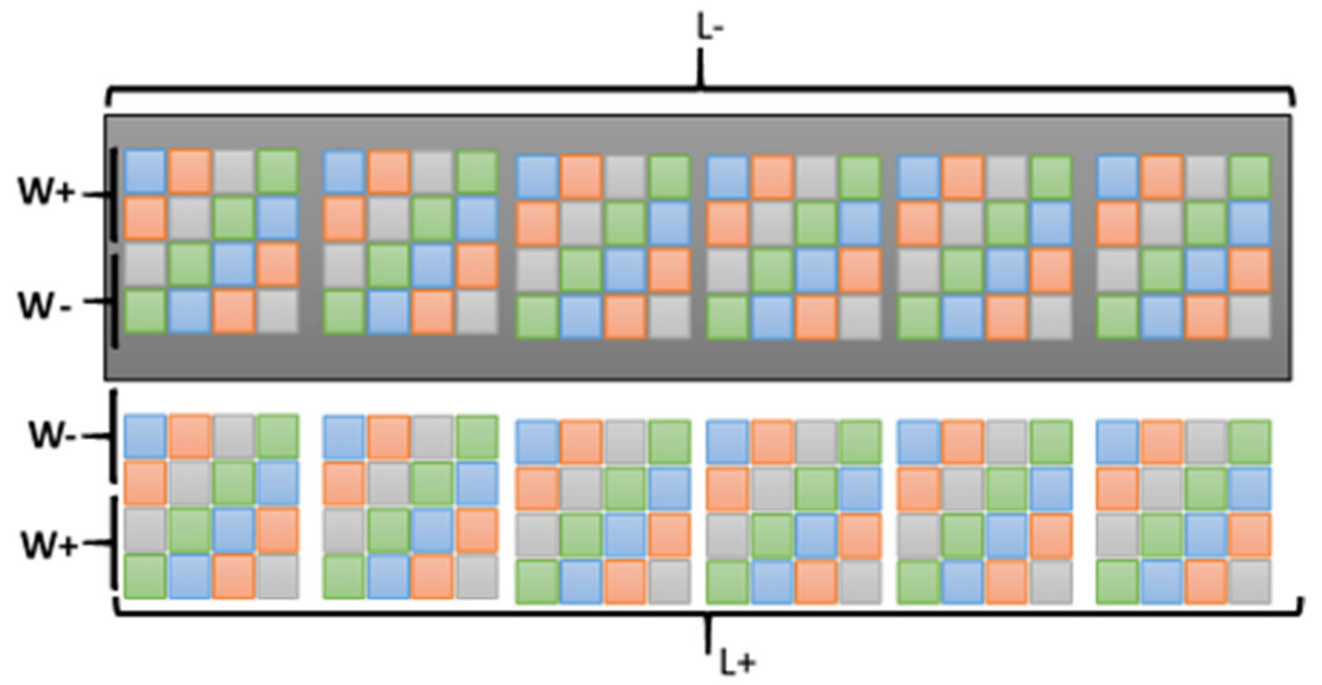

Figure 2. Seedling arrangement in a split-plot experiment with two factors (light and water availability) of two levels each (light: L+ and L-; water: $\mathrm{W}+$ and $\mathrm{W}-$ ), and treatments replicated in 12 blocks (with 16 seedlings each, 4 seedlings per species). Six blocks were under L- (upper blocks, shaded in gray) and other six blocks were under L+ light conditions (lower blocks). Half of the seedlings in each block within a light condition (ie, 6 seedlings, 2 seedlings per species) were submitted to a different water treatment $(\mathrm{W}+$ or $\mathrm{W}-$ ). Pinus pinea in blue, Juniperus thurifera in red, Quercus faginea in gray and Quercus ilex in green.

In day 394, plants in W- treatment were subjected to a two-month (up to day 467) severe drought experiment, aiming to mimic artificially the effect of summer drought. For this purpose, soil moisture in the $\mathrm{W}$ - treatment was further reduced for two months until reaching $3.5 \pm 0.9 \%$. During this period, plants under $\mathrm{W}+$ treatment were maintained on similar well- watered conditions $(25.6 \pm 0.6 \%)$.

During the whole experiment, seedlings were irrigated individually and soil-water moisture was monitored for each seedling every week using a portable time domain reflectometer (TDR) equipped with three $16 \mathrm{~cm}$ probes (TRIME FM 3, IMKO GmbH, Ettlinger, Germany) (Figure 1). Analysis of variance of soil water moisture at every measuring date indicated no significant differences $(p$-value $>0.05)$ between light levels for seedlings in both watering treatments.

\subsection{Plant Growth and Survival in the Long Term}

During the growing period, seedling survival was monitored weekly. Plant height was measured nine times (day 0, day 55, day 96, day 145, day 225, day 328, day 344, day 394 and day 467). Relative shoot growth (RSG) was calculated as $\mathrm{Y}=[\log (\mathrm{x} 2)-\log (\mathrm{x} 1)] /[\mathrm{t} 2-\mathrm{t} 1]$, where $Y$ is RSG, $x 2$ and $x 1$ represent the final and initial height and $t 2-t 1$ is the time elapsed between these two measurements.

\subsection{Physiological Responses to Severe Drought Experiment}

In day 394, at the beginning of the severe drought experiment, a random subset of five plants per species and watering $x$ light environment combination was selected to determine morphological and physiological resistance to severe summer drought.

Chlorophyll (Chl) a fluorescence, gas-exchange parameters and water status were measured three times, at the beginning, middle and end of the two months length severedrought experiment, on a $5-7 \mathrm{~cm}$ long branch. The three measurements were made in 
the same five seedlings per treatment and species throughout the drought experiment. A portable infrared gas analyser (IRGA LCPro+ Analytical Development Corporation, BioScientific Ltd., Hoddesdon, UK) was used to measure net photosynthesis (An), transpiration rate $(\mathrm{E})$ and stomatal conductance (gs). Gas exchange parameters were measured in the morning at maximum irradiance light of $1500 \mu \mathrm{mol}$ (photon) $\mathrm{m}^{-2} \mathrm{~s}^{-1}$. Temperature was set at $25 \pm 2{ }^{\circ} \mathrm{C}$ and $\mathrm{CO}_{2}$ at $400 \pm 10 \mathrm{ppm}$, vapour pressure deficit inside the leaf chamber was $10.1 \pm 0.2$ mbar. A leaf chamber with broad leaf jaws was used for the two oaks, while the conifer jaws were used for the two conifers. Photosynthesis values were expressed on a leaf area basis. Chl a fluorescence was measured in the same twig with a portable pulse-modulated fluorometer (FMS2, Hansatech Instruments Ltd., Norkfold, UK). For each measuring date, two sets of measurements were recorded, dark-adapted fluorescence (leaves were acclimated to dark for 30 min with dark-adaption leaf clips) and morning light fluorescence, thus measuring the maximum photochemical efficiency of photosystem II (Fv/Fm), the yield of photochemistry in PSII (ФPSII) and the apparent photosynthetic electron transport rate (ETR). Shoot midday water potential was measured using a pressure chamber (Scholander PMS 1000, Instruments Co., Corvallis, OR, USA).

At the end of the experiment different indices of plasticity and drought resistance were calculated. An index of phenotypic plasticity ranging from 0 to 1 was calculated for each morphological (PIm), physiological (PIph)and allometry (PIa) traits and species as the difference between the maximum and the minimum mean values between the four treatment combinations $(\mathrm{L}+\mathrm{W}+, \mathrm{L}+\mathrm{W}-, \mathrm{L}-\mathrm{W}+$, and $\mathrm{L}-\mathrm{W}-)$ divided by the maximum mean value [28]. This index estimates the level of response of the species to the treatment combinations. Once these indices were calculated for all traits and species, an average phenotypic plasticity index for morphological traits (dry weights and growth), allometry (biomass ratios) and physiological traits (gas exchange, fluorescence and water potential) was computed for each species.

We quantified the species' drought resistance (D) based on [29] in the dry treatment $(\mathrm{W}-)$ relative to the irrigated treatment $(\mathrm{W}+)$ for each morphological, physiological and allometry traits, plus survival, as follows:

$$
\mathrm{D}_{\mathrm{k}}=\frac{\mathrm{K}_{(\mathrm{W}-)}}{\mathrm{K}_{(\mathrm{W}+)}} \times 100
$$

For gas exchange parameters and water potential, $\mathrm{K}(\mathrm{W}-)$ and $\mathrm{K}(\mathrm{W}+)$ represent the final values of the measured traits after the two months reduction in soil moisture relative to values at the beginning of the drought period in the dry $(\mathrm{W}-)$ and wet $(\mathrm{W}+)$ treatment, respectively. For the other traits, $\mathrm{K}(\mathrm{W}-)$ and $\mathrm{K}(\mathrm{W}+)$ represent the final values of the measured traits relative to values at the beginning of the experiment, under the dry $(\mathrm{W}-)$ and wet $(\mathrm{W}+)$ treatment. An average drought resistance index for morphological traits (dry weights and growth) (Dm), allometry (Da) physiological traits (gas exchange and water potential) (Dph) and survival (Ds) was calculated.

\subsection{Data Analysis}

The dataset was checked for normality, homoscedasticity and outlier detection A logistic function was fitted to study the effect of water availability and light on survival over time for the different species. A repeated measures analysis of variance was used to analyze the effect of light and water availability on height over time for each species. Height at the moment of transplanting was considered as a covariate. To simultaneously detect the effects of light and water availability for each species and their interaction on the different morphological, physiological and allometry traits, a two-way ANOVA was performed. Tukey tests were performed for comparison of means. Finally, differences between species in terms of plasticity and drought resistance indices were evaluated using a one-way ANOVA. The SAS software was used for all the analyses. 


\section{Results}

\subsection{Plant Survival and Growth in the Long-Term}

The reduction in water availability (treatment $\mathrm{W}-$ ) significantly decreased ( $p$-value $<0.0001$ ) seedling survival in $Q$. faginea seedlings (survival of $29 \%$ at the end of the experiment). $Q$. faginea seedlings grown under high light environment (L+) died even under moderate rates of drought, while seedlings under shaded environments $(\mathrm{L}-$ ) only died after they were submitted to the 2-months severe drought experiment. Survival rates of the other three species were high (100\% in P. pinea, $98 \%$ in J. thurifera and $94 \%$ in Q. ilex), and were not significantly affected by the treatment (Figure 3).

Juniperus thurifera

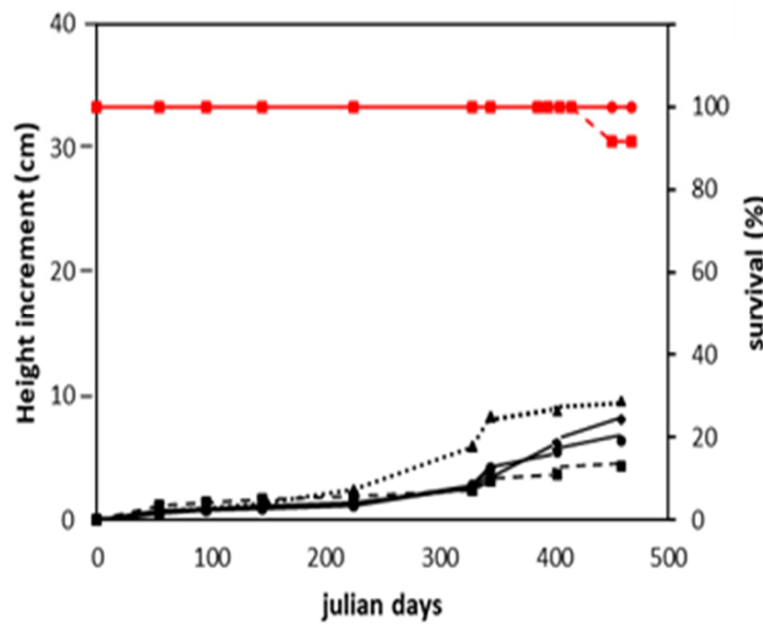

Quercus faginea

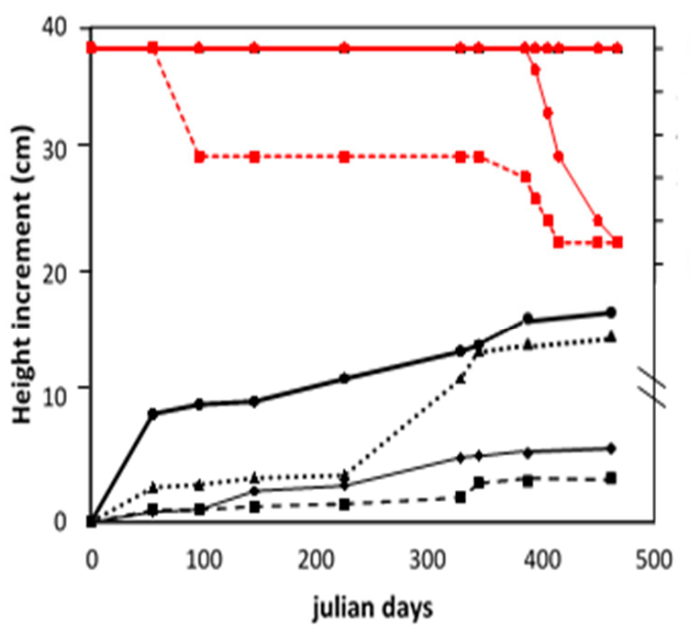

\section{Pinus pinea}

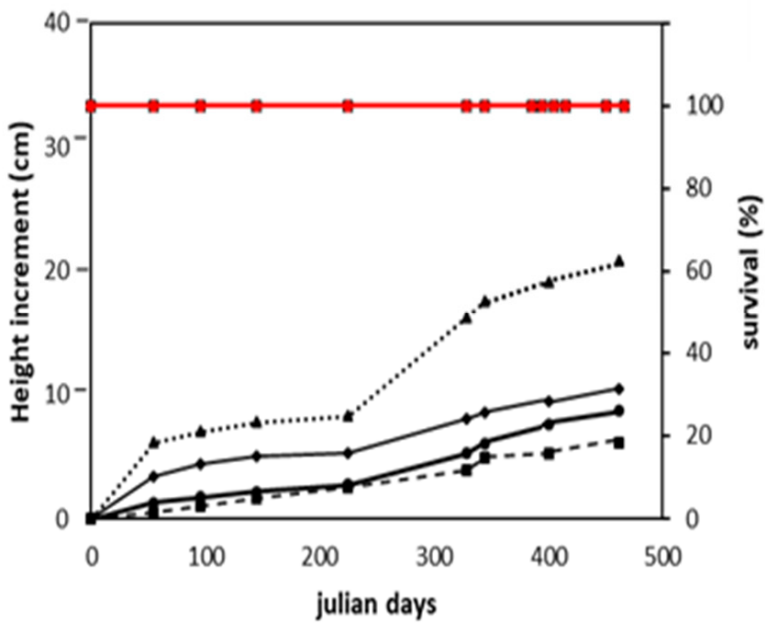

Quercus ilex

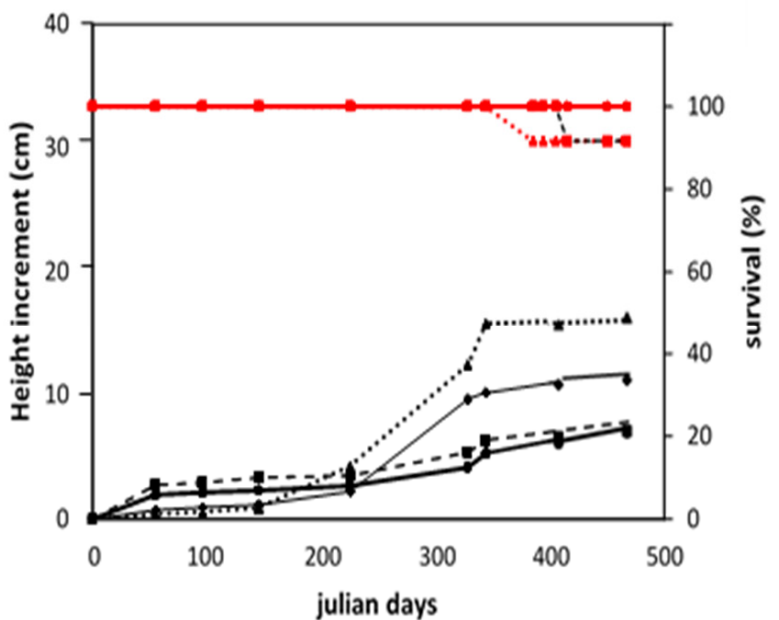

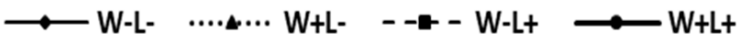

Figure 3. Height increment (cm) (in black) and survival (\%) (in red) during the experimental period for each treatment combination in the four studied species. 
Results of the repeated measures ANOVA showed a significant effect of light and water treatments over time on height ( $p$-value $=0.0008)$. At the end of the experiment, seedlings grown under shade conditions and high water availability $(\mathrm{W}+\mathrm{L}-)$ were the tallest for all species except for $Q$. faginea, which was tallest at full light conditions and high water availability $(\mathrm{W}+\mathrm{L}+)$ (Figure 3$)$. A head start in early growth of seedlings from the large-seeded species (both oak species and P. pinea) was maintained throughout the experimental period, in contrast to the slow-growing pattern observed in J. thurifera. For instance, the effect of treatments on this species was only apparent almost a year after the beginning of the experiment (day 328) (Figure 3).

\subsection{Morphology and Allometry Traits}

Two-way ANOVA over different biomass and allometry traits revealed significant effects of water and light availability depending on the species. Light and water availability significantly affected relative shoot growth (RSG) showing higher relative shoot growth (RSG) values under moderate shade and high water availability $(\mathrm{W}+\mathrm{L}-)$, except for Q. faginea (Table S1). Total dry weight significantly increased with high light availability for J. thurifera and Q. ilex, and with high water availability for $Q$. faginea. Shoot, root and total biomass significantly increased with high water availability and high light $(\mathrm{W}+\mathrm{L}+)$ in the two conifers, while biomass traits were affected either by light (Q. ilex) or by water availability ( $Q$. faginea) in the oak species. Significant interactions between light and water availability were observed in P. pinea for three biomass traits measured, indicating that the positive effect of high light was only shown under high water availability conditions.

Seedlings showed greater investment in shoots than in roots under low light environments $(\mathrm{L}-)$ and high water availability $(\mathrm{W}+)($ Table S1), although significant differences were only detected for P. pinea and Q. ilex (light) and J. thurifera (water availability). Irrespective of treatment, the two oak species showed greater investment in roots than in shoots compared to conifers ( $\mathrm{S} / \mathrm{R}, p$-value $<0.0001$, results not shown). For instance, $66 \%$ of the total biomass in the two oaks was allocated to roots, while for the conifers this figure was only $38 \%$.

Average leaf mass fraction (LMF) decreased significantly with high irradiance (L+) in $Q$. ilex and $Q$. faginea; while it increased with high water availability $(\mathrm{W}+)$ in the two conifers (Figure 4, Table S1). Stem mass fraction (SMF) decreased significantly in the two oak species with high light (L+), while light had no effect on SMF in the two conifers. Root mass fraction (RMF) increased very consistently under high light $(\mathrm{L}+)$ in P. pinea and $Q$. ilex. In P. pinea, SMF increased at the expense of RMF. In the case of high water availability $(\mathrm{W}+)$, on average, allocation shifted from shoot to root, except in Q. faginea (Figure 4).

Higher specific leaf area (SLA) was related to moderate shade (L-) in Q. faginea and $J$. thurifera (Table S1). For all treatment combinations, Q. faginea had higher SLA than the three evergreen species (the two conifers and Q. ilex), while the lowest SLA was recorded in J. thurifera seedlings. 


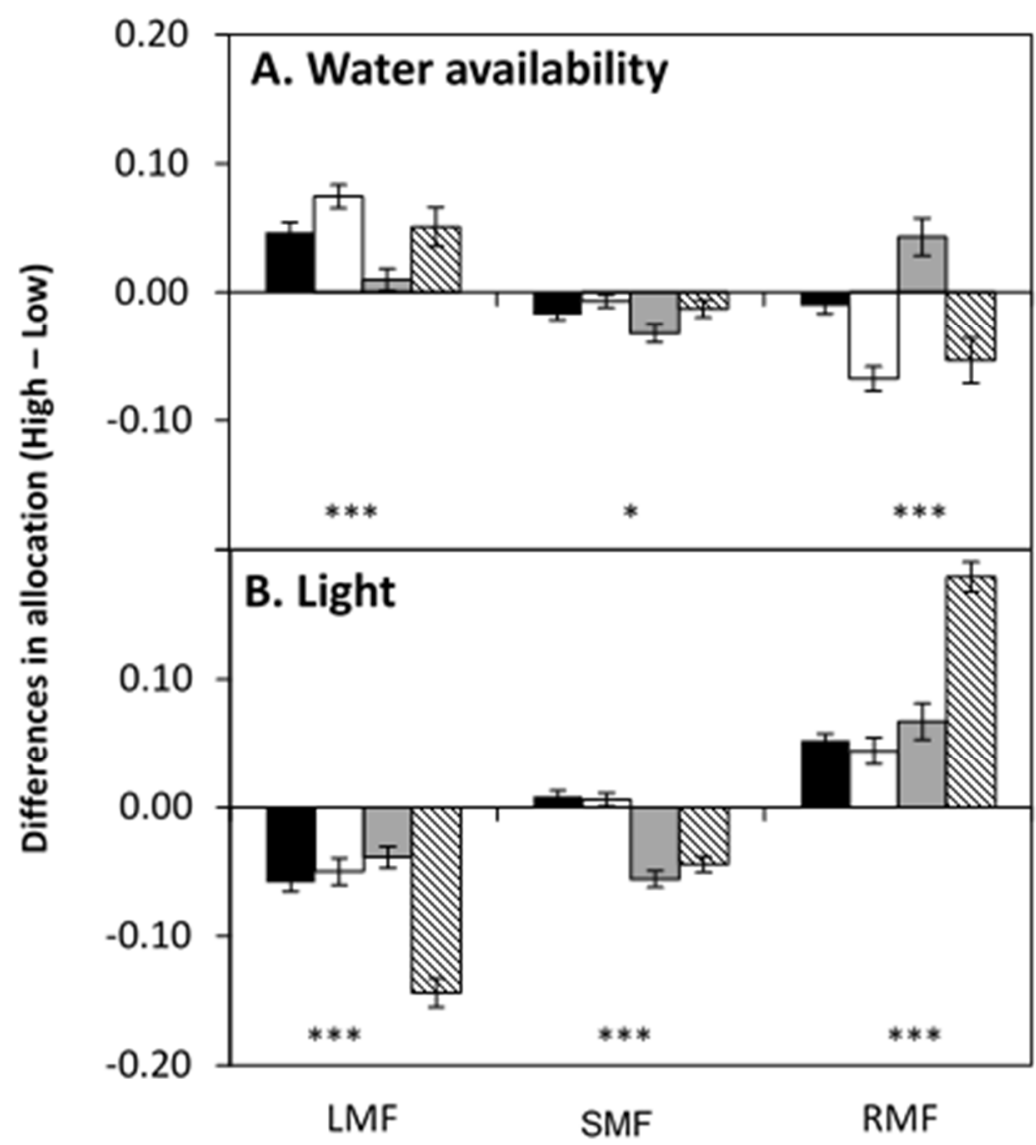

Figure 4. Differences in biomass allocation between plants grown at a high $(\mathrm{W}+$ or $\mathrm{L}+)$ and a low level (W- or L- of resource availability. Average values $( \pm \mathrm{SE})$. (A) Water availability, (B) Light. Asterisks at the bottom of the panels indicate the significance level under the H0 hypothesis of no difference in allocation between species $\left({ }^{*} p<0.05,{ }^{* *} p<0.01,{ }^{* * *} p<0.001\right)$. LMF, leaf mass fraction; $\mathrm{SMF}$, stem mass fraction; RMF, root mass fraction. Pinus pinea (black), Juniperus thurifera (white), Quercus faginea (grey), Quercus ilex (dashed line).

\subsection{Physiological Responses to Severe Drought}

During the 2-months severe drought period, water potential and gas exchange parameters were mainly affected by water availability (higher values in $\mathrm{W}+$ treatment), with no effect of light or the interaction light $x$ water availability. Meanwhile, Fv/Fm changed with the light treatment (higher values for all species in L- treatment) (Table S2).

Water potential decreased significantly over the 2-months severe drought period in the water-stressed seedlings of $P$. pinea $(p$-value $=0.0068)$, J.thurifera $(p$-vale $=0.0064)$ and $Q$. faginea ( $p$-value $=0.0095)$. At the end of this period, water potential for all species was significantly lower in seedlings submitted to water stress (W- compared to well-watered seedlings ( $\mathrm{W}+$ ) (Figure 5). At this moment, values ranged between -0.9 and $-1.1 \mathrm{MPa}$ in well-watered seedlings ( $\mathrm{W}+$ ) and between -1.5 and $-1.9 \mathrm{MPa}$ in water stressed seedlings $(\mathrm{W}-$. Higher water potential was measured in water stressed seedlings $(\mathrm{W}-)$ in P. pinea $(-1.5 \mathrm{MPa})$, compared to $Q$. faginea $(-1.9 \mathrm{MPa})$, with intermediate values of $-1.6 \mathrm{MPa}$ for $J$. thurifera and $-1.8 \mathrm{MPa}$ for $Q$. ilex, although non-significant differences between species were detected $(p$-value $=0.1466)$.

Net photosynthesis (An) of water-stressed seedlings significantly decreased over the 2-months severe drought period in all species except $J$. thurifera that maintained a relatively constant An $\left(9.2 \mu \mathrm{mol} \mathrm{CO} \mathrm{Cm}^{-2} \mathrm{~s}^{-1}\right)$. Especially significant was the decrease shown by $P$. pinea and $Q$. faginea water-stressed seedlings over the 2 months, compared to well-watered seedlings. Meanwhile, $Q$. ilex was able to maintain a significantly higher An under water stress at the end of the period, compared to the other three species $(p$-value $=0.0049)$ (Figure 5). 


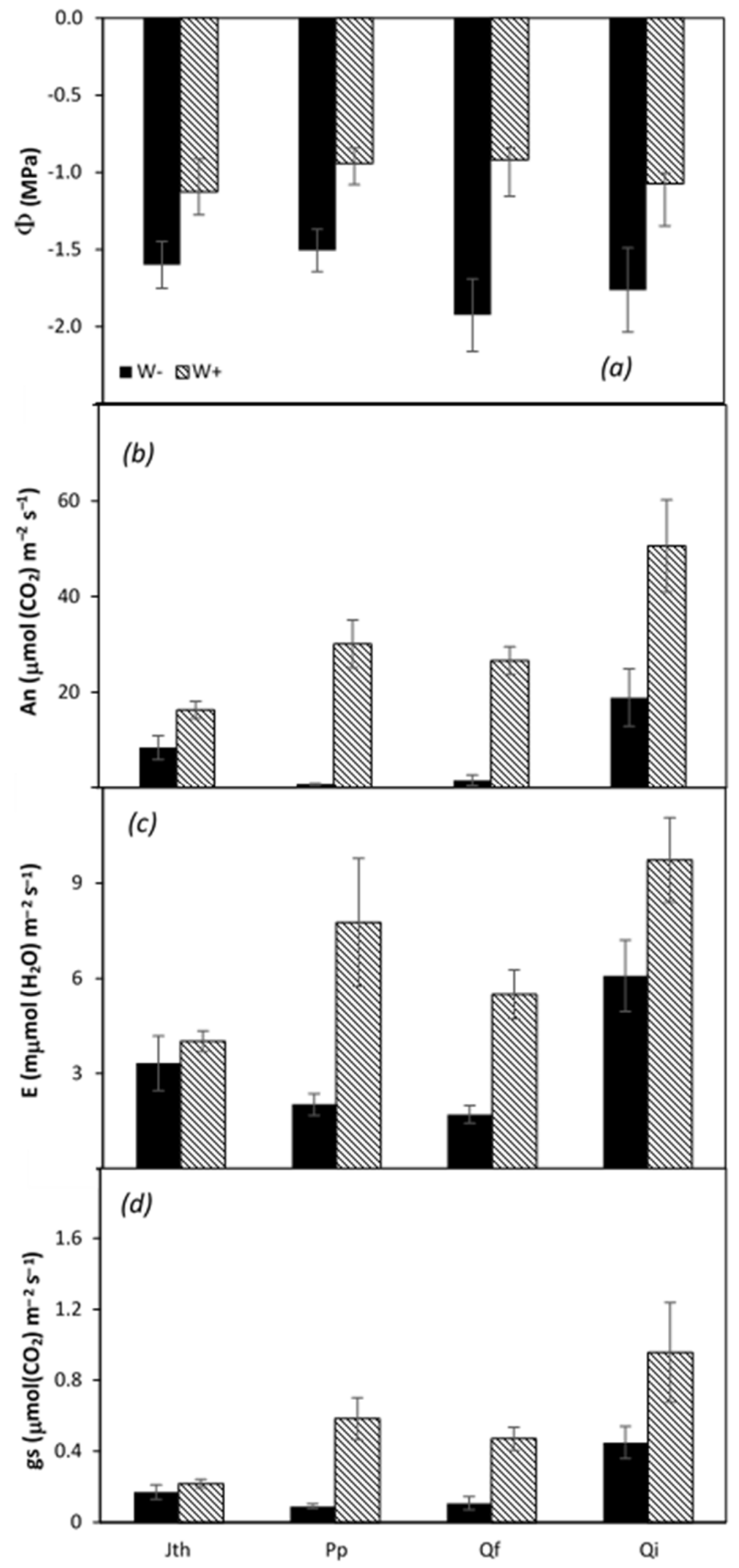

Figure 5. (a) Water potential $(\Phi, \mathrm{MPa})$, (b) net photosynthesis $\left(\mathrm{An}, \mu \mathrm{mol}\left(\mathrm{CO}_{2}\right) \mathrm{m}^{-2} \mathrm{~s}^{-1}\right)$, (c) transpiration $\left(\mathrm{E}, \mathrm{mmol}\left(\mathrm{H}_{2} \mathrm{O}\right) \mathrm{m}^{-2} \mathrm{~s}^{-1}\right)$ and (d) stomatal conductance $\left(\mathrm{gs}, \mu \mathrm{mol}\left(\mathrm{CO}_{2}\right) \mathrm{m}^{-2} \mathrm{~s}^{-1}\right)$ in water stressed $(\mathrm{W}-)$ vs. well-watered $(\mathrm{W}+)$ seedlings of the four studied species, after the 2-months severe drought period (Jth: Juniperus thurifera, Pp: Pinus pinea, Qf: Quercus faginea, Qi: Quercus ilex). See Table S2 for statistical significance. 
Transpiration (E) and stomatal conductance (gs) of water-stressed seedlings decreased over the 2-months drought period in water-stressed seedlings of P. pinea and $Q$. faginea. Meanwhile, J.thurifera and $Q$. ilex maintained relatively constant values (Table S2) (E values: $3.3 \mathrm{mmol} \mathrm{H}_{2} \mathrm{O} \mathrm{m}^{-2} \mathrm{~s}^{-1}$ in J. thurifera, $6.7 \mathrm{mmol} \mathrm{mmol} \mathrm{H}_{2} 0 \mathrm{~m}^{-2} \mathrm{~s}^{-1}$ in $Q$. ilex; gs values: $0.19 \mu \mathrm{mol} \mathrm{CO}_{2} \mathrm{~m}^{-2} \mathrm{~s}^{-1}$ in J. thurifera, $0.67 \mu \mathrm{mol} \mathrm{CO}_{2} \mathrm{~m}^{-2} \mathrm{~s}^{-1}$ in $Q$. ilex). Significantly higher transpiration and stomatal conductance were recorded in waterstressed $Q$. ilex seedlings compared to the other species along the 2-months drought period ( $p$-value $<0.05)$. Similar to photosynthesis, after the 2 -months period, transpiration was significantly lower in seedlings submitted to water stress $(\mathrm{W}-)$ compared to well-watered seedlings $(\mathrm{W}+)$, except for $J$. thurifera. Regarding stomatal conductance, significant differences were shown between the water availability treatments in $P$. pinea $(p$-value $=0.0022)$ and $Q$. faginea ( $p$-value $=0.0002$ ) (Figure 5).

After the 2-months drought period, only $Q$. faginea seedlings under the water-stressed treatment $(\mathrm{W}-)$, responded differently to light $(\mathrm{L}+\mathrm{vs}$. $\mathrm{L}-$ ) for net photosynthesis $(p$-value $=0.0489)$, transpiration $(p$-value $=0.0291)$, stomatal conductance $(p$-value $=0.0365)$, PSII ( $p$-value $=0.0127)$ and SLA $(p$-value $=0.0123)$.

\subsection{Drought Resistance and Trait Plasticity}

At the end of the experiment significant differences in the drought resistance indices between species were observed (Table 1). Significant higher drought resistance index for physiological traits was shown in J. thurifera compared to P. pinea and $Q$. faginea $(p$-value $=0.0474)$. Regarding drought resistance index for morphological traits, higher drought resistance indices were shown in $Q$. ilex compared with the other three species ( $p$-value $<0.0001)$. The lowest drought resistance in terms of survival was recorded in $Q$. faginea ( $p$-value $<0.0001)$. No significant differences between species were shown for drought resistance in terms of allometry.

Table 1. Mean and ANOVA results (F-statistic value and probability levels) of the effect of species on drought resistance indices (Da, Dph, Dm and Ds) and plasticity indices.

\begin{tabular}{|c|c|c|c|c|c|c|c|}
\hline & & $\begin{array}{c}\text { Juniperus } \\
\text { thurifera }\end{array}$ & Pinus pinea & $\begin{array}{l}\text { Quercus } \\
\text { faginea }\end{array}$ & Quercus ilex & $\mathbf{F}$ & $p$-Value \\
\hline \multirow{4}{*}{$\begin{array}{l}\text { Drought } \\
\text { resistance } \\
\text { indices }\end{array}$} & $\mathrm{Da}$ & 92.81 & 96.42 & 110.78 & 94.49 & 1.33 & ns \\
\hline & Dph & 81.00 & 54.27 & 56.24 & 74.95 & 2.83 & 0.0474 \\
\hline & $\mathrm{Dm}$ & 71.96 & 58.23 & 54.11 & 103.07 & 9.33 & 0.0001 \\
\hline & Ds & 95.83 & 100 & 29.17 & 91.29 & 25.45 & 0.0001 \\
\hline \multirow{3}{*}{$\begin{array}{c}\text { Plasticity } \\
\text { indices }\end{array}$} & PIa & 0.449 & 0.327 & 0.655 & 0.480 & 7.12 & 0.0005 \\
\hline & PIph & 0.615 & 0.696 & 0.703 & 0.652 & 0.31 & ns \\
\hline & PIm & 0.655 & 0.635 & 1.255 & 0.780 & 1.70 & ns \\
\hline
\end{tabular}

Drought resistance index for morphological traits (dry weights and growth) (Dm), allometry (Da), physiological traits (gas exchange and water potential) (Dph) and survival (Ds). Average phenotypic plasticity index for morphological traits (dry weights and growth) (PIm), allometry (PIa) and physiological traits (gas exchange and water potential) (PIph).

Differences between species were significant for the phenotypic plasticity indices related to allometry ( $p$-value $=0.0005)$, thus $Q$. faginea showed higher allometric plasticity than the two conifers, while no significant difference between species were observed on neither physiological nor morphological plasticity indices (Table 1).

\section{Discussion}

Seedlings of the four Mediterranean tree species studied developed different mechanisms of tolerance and avoidance, together with different functional and morphological traits to deal with the interactive effect of water shortage and light availability during the early phases of growth. Such interactive effect of water availability and light was both trait- and species-dependent. Thus, a significant interactive effect was mainly shown for growth and morphology traits, while survival, physiological traits and allometry were 
affected either by water availability or by light depending on the trait considered but being more remarkable the effect of water availability over light. The most outstanding species-dependent effect was that of drought on Q. faginea's survival, as drought severely limited the survival of the species under both light intensities (Table 2).

Table 2. Schematic representation of the main significant effects of treatments (water availability (W) in blue, light (L) in yellow, water availability and light (W,L) in green, no effect in white) on the different traits studied on the four species, at the end of the experiment.

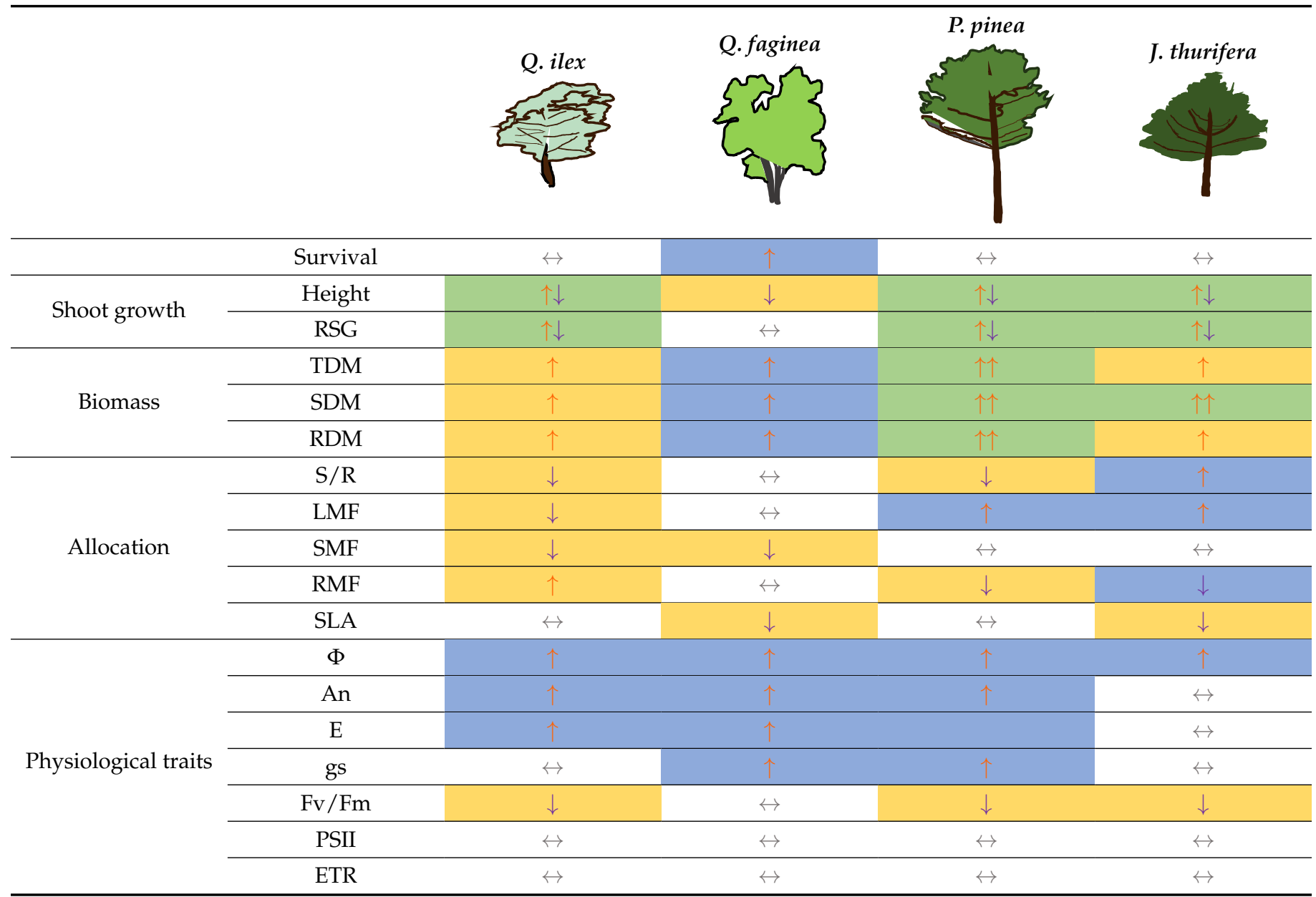

Upwards-orange arrows indicate a positive effect of $\mathrm{W}+$ or $\mathrm{L}+$ on the studied trait; Downwards-purple arrow indicate positive effect of $\mathrm{W}$-or $\mathrm{L}-$ on the studied trait; horizontal- gray arrows indicate no treatment effect; when two arrows are together, the first indicates the effect of water availability and the second indicates the effect of light.

In the long-term, the four species showed higher shoot growth under moderate shade and high water availability $(\mathrm{W}+\mathrm{L}-)$. This result is consistent with theories and empirical data on habitat-related traits, which suggest that species adapted to high-resource environments show higher growth, high potential rates of resource capture and high tissue metabolic rates (and associated morphological traits) relative to species characteristic of low-resource environments (e.g., [30]).

The higher plasticity of oaks (mainly Q. faginea) in biomass partitioning patterns (shoot to root ratio, leaf, stem and root mass fractions, and specific leaf area) constitute one of the most outstanding divergences between oaks and conifers. Under moderate shade and high water availability conditions, a common pattern of biomass allocation to stems and leaves at the expense of roots in the two oak species [31] suggests a relationship between shoot mass fraction (SMF) and the leaf habit [32]. 
The small-seeded $J$. thurifera and the resprouter $Q$. ilex were able to maintain relatively constant values (or with small decreases) of gas exchange parameters along the 2-months drought period, irrespective of the light environment; meanwhile, P. pinea and $Q$. faginea suffered remarkable decreases in these measured traits. Additionally, the relatively low decrease in gas exchange parameters in J. thurifera and $Q$. ilex ran in parallel to intermediate midday water potentials in these two species. Consequently, both species, but mainly J. thurifera, showed higher drought resistance indices in the physiological traits compared to $P$. pinea and $Q$. faginea. In the case of $J$. thurifera, such effect was even more remarkable when seedlings were grown under shade.

The higher drought resistance of $J$. thurifera seedlings to the combination of light and water availability in terms of physiological traits could confer an adaptive advantage to this species. As reported by [27], J. thurifera is colonizing the abandoned agricultural land in central Spain, where seedling survival and establishment is assured as long as sporadic recruitment windows with wet episodes are maintained. This ability to colonize recently abandoned land is intimately related to lower competition in these areas, as the distribution of $J$. thurifera has historically been considered to be limited by competition with species which have higher growth rates and faster life cycles [33].

Apart from maintaining an active physiological performance during the 2-months severe drought period, $Q$. ilex showed also higher drought resistance for the morphological traits. Additionally, the species showed higher plasticity in the morphological traits under shade. The pattern of biomass allocation to stems and leaves at the expense of roots typical in oak species [31] allows higher relative shoot growth compared to the two conifers, thus conferring an advantage under drought conditions, particularly to the evergreen $Q$. ilex. Increased allocation to roots under conditions of low water availability has been previously reported in Q. ilex (e.g., [34]). For instance, when growing in drought-prone environments under high irradiance, $Q$. ilex tends to develop large taproots to reach deeper soil layers [35], thus facilitating the exploitation of even small increases in soil moisture after isolated summer rainfall events [36]. This is an advantage for $Q$. ilex, as the typical sandy soils at the Northern Plateau suffer a rapid water loss due to drainage, so the optimal moisture conditions are only present for a few days in spring and autumn, just after the rainfall events. In these drought-prone environments, the multistratified root system of $P$. pinea [37] may also confer a competitive advantage to this species, although it does not benefit from sporadic summer rainfall events to the same degree as $Q$. ilex [38]. This fact, together with its higher plasticity to morphological traits, its active physiological performance during drought and its wider thermal amplitude, must be seen as an advantage for $Q$. ilex in mixed pine-oak-juniper stands in drought-prone environments.

Regarding $Q$. faginea, their seedlings showed low gas exchange activity as drought conditions aggravated, even endangering its survival; and such effects were independent on light conditions. For instance, $Q$. faginea showed the lowest drought resistance to drought in terms of survival. Similar to $Q$. faginea, P. pinea showed low gas exchange activity under drought conditions, irrespective of the light environment. However, P. pinea was able to maintain the highest water potential after the 2-months drought period, while $Q$. faginea's water potential decreased the most.

Seedlings growth, morphology and allometry in $Q$. faginea and P. pinea were also negatively affected by drought. Thus, seedlings of $P$. pinea and $Q$. faginea seemed to show a higher performance in terms of growth, morphology, allometry and gas exchange traits when water was not a limiting factor, being the effect of water availability mediated by light mainly in $P$. pinea. For instance, $P$. pinea showed higher morphological performance under low resource availability ( $\mathrm{L}-\mathrm{W}-)$, compared to the other species, especially as regards shoot development (higher leaf, stem and shoot mass fractions and shoot to root ratio). Under such environment, this species showed high net photosynthesis (An), while maintaining a relatively high water potential, well beyond the risk of catastrophic xylem failure. For instance, the optimal regeneration niche for the species in the Spanish Northern Plateaus 
(in terms of growth and survival) is found on mid-shaded locations, suggesting that, under drier locations, it is benefited by shelter from excessive radiation [39].

Although Q. faginea developed a deeper root system (greater root dry weight and root mass fraction), a greater SLA to adjust leaf morphology and a high An than the other species under $\mathrm{L}-\mathrm{W}$ - conditions, these environmental conditions had a negative effect on Q. faginea survival. This is intimately related to the lower water potential measured, which is a direct consequence of extreme dependence of the species on soil water reserves. There is strong evidence that a moderately shaded environment is beneficial for oak seedlings, at least during the early stages [40]. However, the benefits of shade should be associated with higher soil water content, which is not the case. Thus, the shade conditions in this experiment seemed to ameliorate the impact of drought on $P$. pinea while they negatively affected the performance of $Q$. faginea, due its low plastic response to the light environment as regards leaf and root allocation, which is consistent with the low response observed in more shade tolerant species [41].

In particular, there is a continuum of water use strategies to cope with water stress, representing $P$. pinea (the highest midday water potential) and Q. faginea (the lowest midday water potential) the opposite ends of this spectrum. Such performance could confer a physiological adaptive advantage to J. thurifera and Q. ilex over the other two species, enabling them to colonize high-water availability early-successional sites.

In summary, according to our results, despite the low growth of $J$. thurifera seedlings in early growth stages that could affect its ability to compete for soil moisture, the species showed a high plasticity to light and water availability in the physiological traits. This fact, joined to its ability to use the water from the sporadic summer and autumn rainfalls [38] and its high resistance to frost events [42] will confer the species with an adaptive advantage in these early growth stages compared with the other three species. For instance, survival of $J$. thurifera seedlings is higher than that of P. pinea in the mixed pine-oak-juniper stand of Central Spain [43]. Similar to J. thurifera, Q. ilex seedlings also show a high plasticity to treatments, mainly related to the allometric traits and some physiological traits (photosynthesis rate and water potential). The large taproot that facilitates the exploitation of deeper soil layers, joined to its resprouting ability and its marked anysohidric behaviour benefited the species in these mixed stands. The high sensitivity of $Q$. faginea to drought will restrict its presence to the most mesic sites within the mixed pine-oak-juniper stands, where water and shade are available. However, while the shade conditions in this experiment seemed to ameliorate the drought impact on P. pinea seedlings, they aggravated Q. faginea performance.

\section{Conclusions}

The four species studied are able to develop different mechanisms of tolerance and avoidance to deal with the interactive effect of water and light availability during the early phases of growth which will facilitate their coexistence and allow complementarity. However, regeneration dynamics in mixed pine-oak-juniper stands in the Northern Plateau, formerly dominated by P. pinea as a result of management to promote pine nut production, will be affected in the mid-term. For instance, a modelling approach on sapling recruitment in these stands, revealed successional trajectories towards J. thurifera and Q. ilex in the long-term [44]. The high plasticity of J. thurifera (physiological traits) and Q. ilex seedlings (physiological and allometric traits) to different light and water availability environments, and their ability to benefit from sporadic summer rainfall events will confer these two species with an adaptive advantage in the early growth stages in comparison with P. pinea and $Q$. faginea seedlings. The high vulnerability of $Q$. faginea seedlings to an increment in aridity will restrict its presence to the most mesic sites within the mixed pine-oak-juniper stands, where water and shade are available. In contrast, the low competitive capacity of $P$. pinea seedlings could restrict its presence to drought-prone shaded environments.

If future climate predictions in Mediterranean continental areas are met, these mixed stands could be likely transformed in the long-term into $Q$. ilex coppice forests, with sparse 
P. pinea trees, only some Q. faginea in the more mesic spots, and an expansion of $J$. thurifera. J. thurifera will undoubtedly keep colonizing these mixed stands, while $Q$. ilex will greatly rely in its resprouting capacity. Thus, to maintain the codominance of the four species in the Northern Plateau, silvicultural interventions should focus on the joint management of the four species, lowering P. pinea densities and promoting the higher plasticity of $Q$. ilex and J. thurifera, while maintaining $Q$. faginea in mesic sites.

Supplementary Materials: The following supporting information can be downloaded at: https: / / www.mdpi.com/article/10.3390/f13020154/s1, Table S1: Least squares mean value and ANOVA results of the effect of light and water availability on morphological traits and allometry, Table S2: ANOVA results of the effect of light (L), water availability $(\mathrm{W})$ and interaction $(\mathrm{WxL})$ on chlorophyll (Chl) a fluorescence (Fv/Fm, PSII, ETR), gas exchange (An, E, gs) and water status $(\Phi)$.

Author Contributions: Conceptualization, M.P. and R.C.; methodology, M.P. and R.C.; formal analysis, M.P. and R.C.; investigation, M.P. and R.C.; resources, M.P. and R.C.; writing-original draft preparation, M.P. and R.C.; project supervision, M.P. and R.C.; project administration, M.P. and R.C.; funding acquisition, M.P. and R.C. All authors have read and agreed to the published version of the manuscript.

Funding: This research was funded by Ministerio de Ciencia e Innovación, grant number AGL201783828-C2-1-R.

Acknowledgments: We are especially grateful to M. Conde and G. Madrigal for technical support in the greenhouse. The plant was provided by the Forest Service of Castilla y León administration.

Conflicts of Interest: The authors declare no conflict of interest.

\section{References}

1. Canham, C.D. Growth and canopy architecture of shade-tolerant trees: Response to canopy gaps. Ecology 1988, 69, 786-795. [CrossRef]

2. Kobe, R.K.; Pacala, S.W.; Silander, J.A.; Canham, C.D. Juvenile tree survivorship as a component of shade tolerance. Ecol. Appl. 1995, 5, 517-532. [CrossRef]

3. Holmgren, M.; Gómez-Aparicio, L.; Quero, J.L.; Valladares, F. Non-linear effects of drought under shade: Reconciling physiological and ecological models in plant communities. Oecologia 2012, 169, 293-305. [CrossRef]

4. Valladares, F.; Matesanz, S.; Guilhaumon, F.; Araújo, M.B.; Balaguer, L.; Benito-Garzón, M.; Cornwell, W.; Gianoli, E.; van Kleunen, M.; Naya, D.E.; et al. The effects of phenotypic plasticity and local adaptation on forecasts of species range shifts under climate change. Ecol. Lett. 2014, 17, 1351-1364. [CrossRef]

5. Quero, J.L.; Villa, R.; Marañón, T.; Zamora, R. Interactions of drought and shade effects on seedlings of four Quercus species: Physiological and structural leaf responses. New Phytol. 2006, 170, 819-834. [CrossRef]

6. Sack, L. Responses of temperate woody seedlings to shade and drought: Do trade-offs limit potential niche differentiation? Oikos 2004, 107, 110-127. [CrossRef]

7. Valladares, F.; Dobarro, I.; Sánchez-Gómez, D.; Pearcy, R.W. Photoinhibition and drought in Mediterranean woody saplings: Scaling effects and interactions in sun and shade phenotypes. J. Exp. Bot. 2005, 56, 483-494. [CrossRef]

8. Calama, R.; Puértolas, J.; Madrigal, G.; Pardos, M. Modeling the environmental response of leaf net photosynthesis in Pinus pinea L. natural regeneration. Ecol. Model. 2013, 251, 9-21. [CrossRef]

9. Mayoral, C.; Pardos, M.; Sánchez-González, M.; Brendel, O.; Pita, P. Ecological implications of different water use strategies in three coexisting Mediterranean tree species. For. Ecol. Manag. 2016, 382, 76-87. [CrossRef]

10. Caselli, M.; Urretavizcaya, M.A.; Loguercio, G.A.; Defossé, G.E. Light and Moisture Conditions Suitable forEstablishing Andean Cypress and Coihue Beech Seedlings in Patagonia: A Nursery Approach. For. Sci. 2018, 65, 27-39.

11. Lindner, M.; Calama, R. Climate change and the need for adaptation in Mediterranean forests. In Forest Management of Mediterranean Forests under the New Context of Climate Change. Building Alternatives for the Coming Future; Lucas-Borja, N.E., Ed.; Nova Science Publishers: New York, NY, USA, 2013; pp. 13-30.

12. Pardos, M.; Calama, R. Responses of Pinus pinea seedlings to moderate drought and shade: Is the provenance a differential factor? Photosynthetica 2018, 55, 1-13. [CrossRef]

13. Valladares, F.; Bastias, C.C.; Godoy, O.; Granda, E.; Escudero, A. Species coexistence in a changing world. Front. Plant Sci. 2015, 6, 866. [CrossRef]

14. Manso, R.; Pukkala, R.; Pardos, M.; Miina, J.; Calama, R. Modelling Pinus pinea forest management to attain natural regeneration under present and future climatic scenarios. Can. J. For. Res. 2014, 44, 250-262. [CrossRef] 
15. Sperlich, D.; Chang, C.T.; Peñuelas, J.; Gracia, C.; Sabaté, S. Seasonal variability of foliar photosynthetic and morphological traits and drought impacts in a Mediterranean mixed forest. Tree Physiol. 2015, 35, 501-520. [CrossRef]

16. Granda, E.; Camarero, J.J.; Gimeno, T.E.; Martinez-Fernandez, J.; Valladares, F. Intensity and timing of warming and drought differentially affect growth patterns of co-occurring Mediterranean tree species. Eur. J. For. Res. 2013, 132, 469-480. [CrossRef]

17. Zhang, S.B.; Zhang, J.L.; Cao, K.F. Divergent hydraulic safety strategies in three co-occurring Anacardiaceae tree species in a Chinese savanna. Front. Plant Sci. 2017, 7, 2075. [CrossRef]

18. Matias, L.; Pérez-Ramos, I.M.; Gómez-Aparicio, L. Are northern-edge populations of cork oak more sensitive to drought than those of the southern edge? Environ. Exp. Bot. 2019, 163, 78-85. [CrossRef]

19. Freschet, G.T.; Violle, C.; Bourget, M.Y.; Scherer-Lorenzen, M.; Fort, F. Allocation, morphology, physiology, architecture: The multiple facets of plant above- and below ground response to resource stress. New Phytol. 2018, 219, 1338-1352. [CrossRef]

20. Reich, P.B.; Wright, I.J.; Lusk, C.H. Predicting leafphysiology from simpleplant and climate attributes: A global GLOPNET analysis. Ecol. Appl. 2007, 17, 1982-1988. [CrossRef]

21. Benito Garzón, M.; Alía, R.; Robson, T.M.; Zavala, M.A. Intra-specific variability and plasticity influence potential tree species distributions under climate change. Glob. Ecol. Biogeogr. 2011, 20, 766-778. [CrossRef]

22. Bussotti, F.; Pollastrini, M.; Holland, V.; Brüggemann, W. Functional traits and adaptive capacity of European forests to climate change. Environ. Exp. Bot. 2015, 111, 91-113. [CrossRef]

23. Kerr, K.L.; Meinzer, F.C.; McCulloh, K.A.; Woodruff, D.R.; Marias, D.E. Expression of functional traits during seedling establishment in two populations of Pinus ponderosa from contrasting climates. Tree Physiol. 2015, 35, 535-548. [CrossRef]

24. Kimball, S.; Gremer, J.R.; Angert, A.L.; Huxman, T.E.; Venable, D.L. Fitness and physiology in a variable environment. Oecologia 2012, 169, 319-329. [CrossRef]

25. Camarero, J.J.; Sanguesa-Barreda, G.; Vergarechea, M. Prior height, growth, and wood anatomy differently predispose to drought-indiced dieback in two Mediterranean oak species. Ann. For. Sci. 2016, 73, 341-351. [CrossRef]

26. DeSoto, L.; Olano, J.M.; Rozas, V. Secondary growth and carbohydrate storage patterns 560 differ between sexes in Juniperus thurifera. Front. Plant. Sci. 2016, 7, 723. [CrossRef]

27. Gimeno, T.E.; Escudero, A.; Delgado, A.; Valladares, F. Previous land use alters the effect of climate change and facilitation on expanding woodlands of Juniperus thurifera. Ecosystems 2012, 15, 564-579. [CrossRef]

28. Valladares, F.; Wright, J.; Lasso, E.; Kitajima, K.; Pearcy, R.W. Plastic phenotypic response to light of 16 congeneric shrubs from a Panamanian rainforest. Ecology 2000, 81, 1925-1936. [CrossRef]

29. Engelbrecht, M.J.; Kursar, T.A. Comparative drought-resistance of seedlings of 28 species of co-occurring tropical woody plants. Oecologia 2003, 136, 383-393. [CrossRef]

30. Reich, P.B.; Tjoelker, M.G.; Walters, M.B.; Vanderklein, D.W.; Buschena, C. Close association of RGR, leaf and root morphology, seed mass and shade tolerance in seedlings of nine boreal tree species grown in high and low light. Funct. Ecol. 1998, 12, 327-338 [CrossRef]

31. Poorter, H.; Niklas, K.J.; Reich, P.B.; Oleksyn, J.; Poot, P.; Mommer, L. Biomass allocation to leaves, stems and roots: Meta-analyses of interspecific variation and environmental control. New Phytol. 2012, 193, 30-50. [CrossRef]

32. Chmura, D.J.; Modrzynski, J.; Chmielarz, P.; Tjoelker, M.G. Plasticity in seedling morphology, biomass allocation and physiology among ten temperate tree species in response to shade tolerance and not leaf habit. Plant Biol. 2017, 19, 172-182. [CrossRef]

33. Montesinos, D.; Fabado, J. Changes in land use and physiological transitions of a Juniperus thurifera forest: From decline to recovery. Can. J. For. Res. 2015, 45, 764-769. [CrossRef]

34. Reich, P.B. Root-shoot relations: Optimality in acclimation and adaptation or the "Emperor's New Clothes". In Plant Roots: The Hidden Half; Elshe, A.K., Ed.; Wailey: New York, NY, USA, 2002; pp. 205-220.

35. Canadell, J.; Jackson, R.B.; Ehleringer, J.B.; Mooney, H.A.; Sala, O.E.; Schulze, E.D. Maximum rooting depth of vegetation types at the global scale. Oecologia 1996, 108, 583-595. [CrossRef]

36. Camarero, J.J.; Olano, J.M.; Parras, A. Plastic bimodal xylogenesis in conifers from continental Mediterranean climates. New Phytol. 2010, 185, 471-480. [CrossRef]

37. Mutke, S.; Calama, R.; González-Martínez, S.C.; Montero, G.; Javier Gordo, F.; Bono, D.; Gil, L. Mediterranean Pinus pinea: Botany and horticulture. In Horticultural Reviews; John Wiley \& Sons, Inc.: Hoboken, NJ, USA, 2012; pp. 153-201.

38. Campelo, F.; Nabais, C.; Freitas, H.; Gutiérrez, E. Climatic significance of tree-ring width and intra-annual density fluctuations in Pinus pinea from a dry Mediterranean area in Portugal. Ann. For. Sci. 2007, 64, 229-238. [CrossRef]

39. Calama, R.; Puértolas, J.; Manso, R.; Pardos, M. Defining the optimal regeneration niche for Pinus pinea L. through physiologybased models for seedling survival and carbon assimilation. Trees 2015, 29, 1761-1771. [CrossRef]

40. Pérez-Ramos, I.; Rodríguez-Calcerrada, J.; Ourcival, J.M.; Rambal, S. Quercus ilex recruitment in a drier world: A multi-stage demographic approach. Perspect. Plant Ecol. Evol. Syst. 2013, 15, 106-117. [CrossRef]

41. Rodríguez-Calcerrada, J.; Pardos, J.A.; Gil, L. Acclimation to light in seedlings of Quercus petraea (Mattuschka) Liebl. and Quercus pyrenaica Willd. planted along a forest-edge gradient. Trees 2007, 21, 45. [CrossRef] 
42. Mayoral, C.; Strimbeck, R.; Sánchez-González, M.; Calama, R.; Pardos, M. Dynamics of frost tolerance during regeneration in a mixed (pine-oak-juniper) Mediterranean forest. Trees 2019, 29, 1893-1906. [CrossRef]

43. Ramírez, M. Estudio de los factores que influyen en la presencia, supervivencia y 620 crecimiento del regenerado de Pinus pinea, Quercus ilex y Juniperus oxycedrus en los Vallesde los ríos Tiétar y Alberche; ETS de Ingeniería de Montes, Forestal y de Medio Natural, UPM: Madrid, Spain, 2017; anexos; 131p.

44. Pardos, M.; Madrigal, G.; de Dios-Garcia, J.; Gordo, J.; Calama, R. Sapling recruitment in mixed stands in the Northern Plateau of Spain: A patch model approach. Trees 2021, 35, 2043-2058. [CrossRef] 